\title{
Propiedades de crecimiento de las líneas celulares DH82 y RF/6A bajo condiciones normales de laboratorio
}

\section{Growth properties of $\mathrm{DH} 82$ and $\mathrm{RF} / 6 \mathrm{~A}$ cell lines under standard laboratory conditions}

\author{
Samara Machuca Figueroaa, Gabriela Granjeno Colínb, Sergio Darío Rodríguez \\ Camarillob, Carlos Agustín Vega y Murguíab
}

\section{RESUMEN}

La línea celular RF/6A ha sido utilizada en estudios de corto plazo evaluando fármacos o infecciones experimentales con Anaplasma marginale; en contraste, DH82 es utilizada para la multiplicación de Ehrlichia canis. No obstante, se desconocen condiciones específicas de su crecimiento, por lo que se diseñaron varios experimentos para resolver interrogantes de su propagación. Ambas líneas, se adquirieron de la American Type Culture Collection, mantenidas en Medio Mínimo Esencial suplementado con suero fetal bovino, piruvato de $\mathrm{Na}$ y $\mathrm{NaHCO}_{3}$ e incubadas en atmósfera de $5 \%$ de $\mathrm{CO}_{2}$ en aire, a $37{ }^{\circ} \mathrm{C}$. Los primeros ensayos, en placas de 24 pozos, esclarecieron los valores de dosis mínima inicial, que fueron 62,500 y 8,836 células/pozo para DH82 y RF/6A; así como los de densidad de siembra; cultivos con concentraciones de 5, 10, 20 y 40 células por $\mathrm{mm}^{2}$, cosechados con solución Tripsina-EDTA al alcanzar $>95 \%$ de confluencia. Los índices estimados fueron: 3,319.32, 1,956.70, 870.73 y 422.14 para DH82 y 62.38, 63.51 , 25.31 y 12.16 veces con RF/6A. La cinética del crecimiento, en cajas de Petri de 35 mm $\varnothing$, incluyó la siembra de 20 células/mm², cambio del medio cada $63 \mathrm{~h}$ y cosecha cada $21 \mathrm{~h}$ para DH82; para RF/6A; la siembra fue 10 células/ $\mathrm{mm}^{2}$, cambio de medio cada $45 \mathrm{~h}$ y cosecha cada $15 \mathrm{~h}$. El máximo crecimiento se observó hasta las 336 y 315 h con tiempos de duplicación de 42.9 y 36.9 h respectivamente para DH82 y RF/6A. Los datos permitieron proponer un modelo patrón de cultivo, para estudios futuros.

PALABRAS CLAVE: Cultivo celular, DH82, RF/6A, Intervalo de duplicación.

\begin{abstract}
DH82 Cell line has been utilized to grow Ehrlichia canis and RF/6A for drug evaluation in short-term cultures, as well as for replicating Anaplasma marginale. However, specific in vitro culture development conditions are unknown. Several experiments were designed to solve inquiries of such procedure. Both cell lines were acquired from ATCC and put into culture. $\mathrm{Na}$ Pyruvate, $\mathrm{NaHCO}_{3}$ and fetal calf serum were used to enrich $\mathrm{MEM}$ culture media and incubated at $37{ }^{\circ} \mathrm{C}$ on $5 \% \mathrm{CO}_{2}$ - air humid mixture atmosphere. First assays used 24 well plates and were focused on determination of a minimum initial cell concentration and cell density. In the former, averages of 62,500 cell/well for DH82 \& 8,836 for RF/6A; were found. Later, experiments to identify a minimum cell density started with $5,10,20 \& 40 \mathrm{cells} / \mathrm{mm} 2$, harvesting with a EDTA-Trypsin solution when confluence be reached. Growth indexes of 3,319.32, 1,956.70, 870.73 \& 422.14 times and of $62.38,63.51,25.31$ \& 12.16 times, were respectively found for DH82 \& RF/6A cell lines. For kinetics studies, $35 \mathrm{~mm} \emptyset$ sterile Petri dishes were used. Cultures were set with 20 cell/mm seed density for DH82 and $10 \mathrm{cell} / \mathrm{mm}^{2}$ for RF/6A. Dishes were randomly separated into two groups, with and without culture media periodical replacement. Maximum growth was observed at 336 and $315 \mathrm{~h}$ with 42.9 and $36.9 \mathrm{~h}$ doubling time in culture, respectively for DH82 \& RF/6A cell lines. Generated data provided a model to define an in vitro growth pattern for future studies.
\end{abstract}

KEY WORDS: Cell culture, DH82, RF/6A, Doubling time.

Recibido el 19 de diciembre del 2014. Aceptado el 6 de mayo de 2015.

a Universidad Politécnica del Estado de Morelos. México.

b Unidad de Anaplasmosis, CENID Parasitología Veterinaria / INIFAP. Carretera Federal Cuernavaca-Cuautla No. 8534, Col. Progreso, C.P. 62550; Jiutepec, Morelos. México. vega.carlos@inifap.gob.mx. Correspondencia al último autor.

Resultados parciales para titulación como Ingeniero en Biotecnología del primer autor. 


\section{INTRODUCCIÓN}

El cultivo celular se precisa como la forma de propagar y mantener fuera del organismo, en condiciones in vitro, células de origen animal o vegetal; que pueden formar monocapa o mantenerse en suspensión manteniendo sus funciones(1). Las líneas celulares son aquellas células que lograron diferenciarse genética y morfológicamente de las estirpes de las que se derivaron, se han mantenido en cultivos continuos $y$ pueden crecer de manera indefinida(2). La línea celular RF/6A(3) cuyo origen es el mono Macaca mulatta ha sido ampliamente utilizada tanto en estudios toxicológicos para evaluar la efectividad de algunos fármacos(4), así como en infecciones con la rickettsia Anaplasma marginale debido a sus propiedades de células endoteliales(5). No obstante, los datos publicados son insuficientes debido a que no se indican condiciones y características específicas de las células en cultivo, los ensayos son de corto plazo y sus datos no son homogéneos o sólo muestran el número de pases(6). La línea DH82 se deriva de un perro (Canis lupus familiaris) de raza Labrador dorado (Golden retriever) de 10 años de edad que padecía histiocitosis maligna $(6,7,8)$ y ha sido utilizada para la multiplicación del microorganismo Ehrlichia canis $(9,10)$ y en su interacción con eritrocitos infectados con Anaplasma marginale(11); recientemente se describió una caracterización inmunológica parcial de la línea celular DH82, en la que se acentuaba la necesidad de generar más información relativa a las propiedades de las líneas celulares(12).

El interés que tiene el Instituto Nacional de Investigaciones Forestales, Agrícolas y Pecuarias de conocer las características de propagación de estas líneas celulares en cultivo, radica en establecer un modelo de estudio para el cultivo in vitro de la rickettsia Anaplasma marginale, agente causal de la anaplasmosis bovina, enfermedad que representa un impacto negativo para la economía ganadera de zonas tropicales de México y el mundo(13,14). Ocupados en dicha

\section{INTRODUCTION}

Cell culture is the process by which animal or plant origin cells are propagated and maintained under in vitro conditions. Once they have been removed from an organism they may form a monolayer or remain in suspension keeping their functions(1). Cell lines are those that become genetically and morphologically differentiated from lineages they were derived and are maintained in continuous culture where they can grow indefinitely(2). Monkey (Macaca mulatta) RF/6A cell line(3) has been widely used in toxicological studies for the evaluation of the effectiveness of several drugs(4), as well as in infections caused by rickettsia Anaplasma marginale, due to its endothelial cell properties(5). However, the published data are insufficient because they do not indicate specific conditions and characteristics of the cell lines, assays are short-term and their data are not homogeneous or they only show the number of passages(6). The DH82 cell line, which derives from a 10-year-old male Golden Retriever (Canis lupus familiaris) with malignant histiocytosis(6-8), has been used for the multiplication of Ehrlichia $\operatorname{canis}(9,10)$ and for its interaction with erythrocytes infected with Anaplasma marginale(11). Recently, a partial immunological characterization of cell line DH82 was described, which accentuated the need to generate further information concerning the properties of cell lines(12).

The interest of the Instituto Nacional de Investigaciones Forestales, Agrícolas y Pecuarias to know about the propagation characteristics of these cell lines lies in establishing a study model for in vitro culture of rickettsia Anaplasma marginale, causative agent of bovine anaplasmosis, disease that has a negative effect on livestock economy in tropical zones of Mexico and worldwide $(13,14)$. In that matter, its purpose is to carry out experiments that allow studying the behaviour of DH82 and RF/6A cell lines before being infected with the microorganism. The objective of the study was to know how both cell lines grow and develop under standard 
problemática se plantea la realización de experimentos que nos permitirán estudiar el comportamiento de las células de las líneas DH82 y RF/6A en cultivo antes de la infección con el microorganismo. El objetivo de la investigación fue conocer el crecimiento y desarrollo de ambas líneas celulares en condiciones normales de laboratorio, para definir un patrón de su comportamiento.

\section{MATERIALES Y MÉTODOS}

Líneas celulares: Ambas líneas, DH82 (Canis lupus familiaris) y RF/6A (Macaca mulatta), utilizadas en esta investigación se obtuvieron comercialmente en forma congelada de "American Type Culture Collection" (ATCC), CRL$10389^{\mathrm{TM}}$ y CRL-1780 ${ }^{\mathrm{TM}}$, respectivamente. Cada una fue rápidamente descongelada en baño maría a $37^{\circ} \mathrm{C}$ y suspendida en medio mínimo esencial (MEM) según formulación de "Eagle", con 2.0 mM L-glutamina (Sigma-AldRICH QuímiCA, SA. de CV Edo. de México; México. No. de Cat. M0643-10x1L) suplementado con $1.0 \mathrm{mM}$ piruvato de $\mathrm{Na}, 1.5 \mathrm{~g} / \mathrm{l}$ de $\mathrm{NaHCO}_{3}$ y $15 \%$ (v/ v) suero fetal bovino inactivado a $56{ }^{\circ} \mathrm{C}$ para la línea DH82 (MEM 15i); para RF/6A se utilizó $10 \%(\mathrm{v} / \mathrm{v})$ de suero fetal bovino sin inactivar (MEM 10). Ambas líneas celulares se adicionaron en una columna de $2 \mathrm{~mm}$ de altura, equivalente a un volumen de $2 \mu \mathrm{l} / \mathrm{mm}^{2}$ y mantenidas por pases sucesivos en botellas de $25 \mathrm{~cm}^{2}$ (CORNING Inc. Corning, NY; EE.UU.; No. de Cat. 430372), con tapón flojo, hasta el momento de su uso experimental. Tanto en el proceso de su mantenimiento como en los ensayos experimentales, los cultivos se incubaron a 37 ${ }^{\circ} \mathrm{C}$ en una atmósfera de $5.0 \%(\mathrm{v} / \mathrm{v})$ de $\mathrm{CO}_{2}$ en aire, saturado de humedad(15).

Experimento de la dosis mínima inicial de DH 82

Para dilucidar la cantidad mínima de células requeridas para iniciar los cultivos, se partió de una concentración de $5.0 \times 10^{5}$ células en su $3^{\mathrm{er}}$ pase, suspendidas en $350 \mu \mathrm{l}$ de medio de cultivo completo MEM15i; realizando diluciones laboratory conditions, in order to define their behaviour pattern.

\section{MATERIAL AND METHODS}

Cell lines: Both lines, DH82 (Canis lupus familiaris) and RF/6A (Macaca mulatta), used in this study were commercially obtained in a frozen form from "American Type Culture Collection" (ATCC), CRL-10389 and CRL-1780 ${ }^{\text {TM }}$, respectively. Each was quickly thawed in water bath at $37{ }^{\circ} \mathrm{C}$ and suspended in Eagle's minimum essential medium (MEM), with 2.0 mM L-glutamine (Sigma-Aldrich Química, SA de CV Edo. de México; México. No. de Cat. MO643$10 \times 1 \mathrm{~L})$ supplemented with $1.0 \mathrm{mM}$ sodium pyruvate, $1.5 \mathrm{~g} / \mathrm{L}$ of $\mathrm{NaHCO}_{3}$ and $15 \%(\mathrm{v} / \mathrm{v})$ inactivated fetal bovine calf serum at $56{ }^{\circ} \mathrm{C}$ for the DH82 cell line (MEM 15i), and for RF/6A, $10 \%(\mathrm{v} / \mathrm{v})$ normal fetal calf serum (MEM 10) was used. Both cell lines were added onto a column of $2 \mathrm{~mm}$ height, equivalent to a volume of $2 \mu \mathrm{l} / \mathrm{mm}^{2}$ and maintained by successive passages in $25 \mathrm{~cm}^{2}$ flasks (CORNING Inc, Corning, NY; EE.UU.; No. of Cat. 430372) with loosen caps, until experimentally used. In the process of maintenance and in the experimental assays, both cultures were incubated at $37^{\circ} \mathrm{C}$ in $5.0 \mathrm{CO}_{2}$ in $\operatorname{air}(\mathrm{v} / \mathrm{v})$ atmosphere under saturated humidity(15).

Minimum seed initial dose for DH82 cell line assay

For determining the minimum number of cells required to start cultures, a concentration of $5.0 \times 10^{5}$ cells (third passage), suspended in $350 \mu \mathrm{l}$ of MEM15i complete cell culture media, was used; performing two-fold dilutions for reducing the inoculum to $2.5 \times 10^{5}, 1.25 \times$ $10^{5}$ and $6.25 \times 10^{4}$ cells suspended in $350 \mu \mathrm{l}$ of MEM15i. Cells were seeded in quadruplicate, inoculating $350 \mu \mathrm{xl} /$ well, using two 24-well plates (CORNING Inc. Corning, NY; EE.UU. No of Cat. 35249). Cell culture media exchange was performed every $72 \mathrm{~h}$ until harvest. which occurred when any of the wells of any treatment reached $\geq 95 \%$ confluence, collecting the 
dobles, para reducir el inóculo a $2.5 \times 10^{5}$, $1.25 \times 10^{5}$ y $6.25 \times 10^{4}$ células suspendidas en $350 \mu$ de MEM15i. Las células se sembraron por cuadruplicado inoculando $350 \mu \mathrm{l} /$ pozo, utilizando dos placas de 24 pozos (CORNING Inc. Corning, NY; EE.UU. No. de Cat. 35249). El cambio del medio se realizó cada 72 h, hasta el momento de la cosecha. Ésta tendría lugar cuando cualquiera de los pozos de cualquier tratamiento llegara a $\geq 95 \%$ de confluencia, cosechándose la totalidad de los pozos mediante disgregación enzimática con $180 \mu \mathrm{l} / \mathrm{pozo}$ de solución $1 X$ de Tripsina-EDTA (Sigma-AldRICH QuímicA, S.A. DE C.V. Toluca, Edo. de México. No. de Cat. 3924) parando la reacción con un volumen igual de medio completo con suero, transfiriendo las células a un microtubo eppendorf de $1.5 \mathrm{ml}$ estéril. Se realizó un lavado por centrifugación a $250 \mathrm{xg}$ durante 15 min a temperatura ambiente (microcentrífuga HERMLE Mod. Z230MA), decantando el sobrenadante y resuspendiendo el paquete celular en un volumen de $180 \mu \mathrm{l}$ de medio completo, empleando un agitador de vórtice. La concentración y viabilidad celular se midió utilizando una muestra de 20 $\mu$ adicionada con $20 \mu$ de una solución $0.15 \%$ $(\mathrm{p} / \mathrm{v})$ de azul de tripano estéril en solución $0.11 \mathrm{M}$ de $\mathrm{NaCl}$; empleando la cámara de Neubauer®. Para el conteo celular se utilizó un microscopio Leica ${ }^{\circledR}$ de campo claro bajo el objetivo 40X, determinándose los valores promedio, error estándar e intervalo de confianza al $95 \%$, aplicando el programa Microsoft Office Excel 2007(16).

Experimento de la dosis mínima inicial de $R F /$ $6 A$

Para identificar la cantidad mínima de células requeridas para iniciar un cultivo de $R F / 6 \mathrm{~A}$, se contaron $5.0 \times 10^{5}$ células en su pase 543 , suspendidas en $350 \mu \mathrm{l}$ de medio de cultivo completo MEM10; realizando diluciones dobles seriadas, para tener una suspensión celular de $2.5 \times 10^{5}, 1.25 \times 10^{5}$ y $6.25 \times 10^{4}$, en una primera fase. Para la segunda fase, el experimento se inició con una concentración celular de $7.07 \times 10^{4}$ células en su pase 551 , contents of all wells by enzymatic dissagregation using $180 \mu \mathrm{l} /$ well of Trypsin/EDTA $1 X$ (SigmaAldrich Química, S.A. de C.V. Toluca, Edo. de México. No of Cat. 3924), stopping the reaction with an equal volume of complete medium with serum and transferring the cells into a sterile $1.5 \mathrm{ml}$ Eppendorf tube. Subsequently, they were washed by centrifugation at $250 \mathrm{xg}$ for $15 \mathrm{~min}$ at room temperature (microcentrifuge HERMLE Model Z230MA), decanting the supernatant and resuspending the cell pellet in a volume of 180 $\mu \mathrm{l}$ of complete medium, using a Vortex Agitator. Cell viability and concentration was measured using a sample of $20 \mu \mathrm{l}$ mixed with $20 \mu \mathrm{l}$ of $0.15 \%(\mathrm{p} / \mathrm{v})$ sterile trypan blue solution in a $0.11 \mathrm{M} \mathrm{NaCl}$ solution; using the Neubauer $\AA$ chamber, in a 40X bright-field Leica $\mathbb{R}$ microscope. Mean values, standard error and $95 \%$ confidence interval, were determined using Microsoft Office Excel 2007(16) program.

\section{Minimum seed initial dose for $R F / 6 A$ assay}

For the determination of the minimal number of cells required to start RF/6A culture, $5.0 \times$ $10^{5}$ cells in passage 543, suspended in $350 \mu \mathrm{l}$ of complete culture medium MEM, were counted; performing two-fold serial dilutions to obtain a cell suspensions of $2.5 \times 10^{5}, 1.25 \times$ $10^{5}$ and $6.25 \times 10^{4}$, in a first trial. For a second trial, the experiment began with a cellular concentration of $7.07 \times 10^{4}$ cells in passage 551 , also performing two-fold serial dilutions to obtain cellular suspensions of $3.53 \times 10^{4}, 1.77 \times$ $10^{4}$ and $8.84 \times 10^{3}$ in $350 \mu$ of MEM10, already described. For both trials, cells in two 24-well plates were inoculated in duplicate with $350 \mu \mathrm{l} /$ well of cell suspension. Cell culture media exchange was performed each $48 \mathrm{~h}$, until harvest, which occurred when cells reached $\geq 95 \%$ confluence in any well and then the totality of wells of each phase was collected. For cell count, the monolayer of confluent cells was disaggregated by enzyme action, using 200 $\mu \mathrm{l} /$ well of $1 \mathrm{X}$ Tripsyn-EDTA solution. After washed by centrifugation, cell viability and concentration were determined by trypan blue 
realizando igualmente diluciones dobles seriadas para obtener una suspensión celular de $3.53 \mathrm{x}$ $10^{4}, 1.77 \times 10^{4}$ y $8.84 \times 10^{3}$ en $350 \mu \mathrm{l}$ del medio MEM10, previamente descrito. En ambas fases, las células se inocularon por duplicado en dos placas de 24 pozos de $350 \mu \mathrm{l} /$ pozo de la suspensión celular. El cambio del medio se realizó cada $48 \mathrm{~h}$, hasta el momento de la cosecha, misma que se realizó al observarse $\geq 95 \%$ de confluencia en algún pozo, cosechándose la totalidad de los pozos de cada fase. Para realizar el conteo de células, la monocapa de células confluente se disgregó por acción enzimática utilizando $200 \mu \mathrm{l} /$ pozo de la solución $1 X$ de Tripsina-EDTA. Después de un lavado por centrifugación, se determinó la concentración y viabilidad celular por la exclusión de azul de tripano, registrándose la descripción y los valores obtenidos, según lo descrito para el primer ensayo.

Experimento de la densidad de siembra de DH82

El objetivo fue conocer el intervalo de tiempo para alcanzar el máximo crecimiento, iniciando los cultivos con diferentes concentraciones celulares. Las células en el $4^{\circ}$ pase se crecieron por duplicado en dos placas de 24 pozos adicionando $350 \mu \mathrm{l} /$ pozo de la suspensión celular, con una densidad de 5, 10, 20 y 40 células $/ \mathrm{mm}^{2}$. Como en el primer experimento, el cambio del medio se realizó cada 72 h, hasta el momento de la cosecha ( $\geq 95 \%$ de confluencia) en cada tratamiento. La concentración y viabilidad celular se determinaron por exclusión del azul tripano, de acuerdo a lo ya descrito y se registraron los valores promedio, error estándar e intervalo de confianza al $95 \%$.

Experimento de la densidad de siembra de RF/ $6 A$

Las células del pase 547 se crecieron en dos placas de 24 pozos empleando el mismo volumen, con densidades de 5, 10, 20 y 40 células $/ \mathrm{mm}^{2}$ por duplicado. El cambio del medio se realizó cada $48 \mathrm{~h}$ hasta el momento de la exclusion, recording obtained values as described in the first assay.

Seed density for DH82 assay

The aim was to know the time interval for reaching maximal growth, initiating the cultures with different cell concentrations. Fourth-passage cells were grown in two 24-well plates in duplicate, adding $350 \mu \mathrm{l} /$ well of cell suspension, with density of $5,10,20$ and 40 cells $/ \mathrm{mm}^{2}$. As in the first assay, cell culture media exchange was performed every $72 \mathrm{~h}$, until all treatments were harvested ( $\geq 95 \%$ confluence). Cell viability and concentration were determined by trypan blue exclusion, as already described and mean values, standard error and $95 \%$ confidence interval were recorded.

Seed density for $R F / 6 A$ assay

After 547 passages, cells were grown in two 24-well plates using the same volume, with densities of $5,10,20$ and 40 cells $/ \mathrm{mm}^{2}$ in duplicate. Cell culture media exchange was performed each $48 \mathrm{~h}$, until harvested, using the same criterion for reaching $\geq 95 \%$ confluence. The enzyme disaggregation was performed using $200 \mu \mathrm{l} /$ well of $1 X$ Tripsyn-EDTA solution, washing the cells by centrifugation. Similarly, viability and number of cells were measured by trypan blue exclusion.

\section{Kinetics of DH82 cell line development}

Cells were expanded up to passage 6 . For this purpose, a cell suspension was prepared for seeding 64 Costar ${ }^{\circledR}$ Petri dishes - $35 \mathrm{~mm} \varnothing \times$ $10 \mathrm{~mm}$ height (Corning Inc. Bellerica, NY, EE.UU. No of Cat. 14831), in volumes of 2,000 $\mu$ l/dish, with a seed density previously determined in the second assay or third trial(15); in terms of 20 cells $/ \mathrm{mm}^{2}$ each, and two groups were formed. No cell culture media exchange was done to half of the dishes (32 units), whereas cell culture media exchange was performed in the remaining 32 dishes, at regular intervals of $63 \mathrm{~h}$. Each $21 \mathrm{~h}$ and until $336 \mathrm{~h}$ of initiation of cultures, two dishes of each group were taken at random, 
cosecha, con el mismo criterio de alcanzar $\geq 95 \%$ de confluencia. La disgregación enzimática se realizó con $200 \mu \mathrm{l} /$ pozo de la misma solución $1 \mathrm{X}$ de Tripsina-EDTA, lavando las células por centrifugación. En forma similar, se midió la viabilidad y número de células, mediante el método de exclusión de azul tripano.

\section{Ensayo de cinética de desarrollo de DH82}

Este experimento se inició con una expansión celular que alcanzó al pase 6 . Para ello, se preparó una suspensión celular suficiente para sembrar con el mismo lote 64 cajas Petri de 35 $\mathrm{mm} \varnothing \times 10 \mathrm{~mm}$ alto, marca Costar $\AA$ (Corning Inc. Bellerica, NY, EE.UU. No. de Cat. 14831), en volúmenes de 2,000 $\mathrm{\mu l} /$ caja, con una densidad de siembra previamente determinada en los ensayos del tercer experimento(15), en términos de 20 células $/ \mathrm{mm}^{2} \mathrm{c} / \mathrm{u}$ y se formaron dos grupos. A la mitad de las cajas, 32 unidades, no se les hizo cambio de medio alguno, mientras que a las 32 unidades restantes el cambio de medio se realizó a intervalos regulares de $63 \mathrm{~h}$. Cada $21 \mathrm{~h}$ y hasta las $336 \mathrm{~h}$ de iniciados los cultivos, se tomaron aleatoriamente dos cajas de cada grupo, cosechando su contenido de la misma manera ya descrita. Al finalizar, se resuspendió el paquete celular en $300 \mu$ de medio completo y determinando su concentración y viabilidad, según lo indicado previamente, tabulando los resultados como valores promedio.

Ensayo de cinética de crecimiento de $R F / 6 \mathrm{~A}$

Este experimento se inició con una expansión celular hasta el pase 551. De la misma manera que en el experimento previo, se preparó una suspensión celular suficiente para sembrar 92 cajas Petri de $35 \mathrm{~mm} \varnothing$ con el mismo pase, en volúmenes de 2,000 $\mathrm{\mu l} / \mathrm{caja}$, con una densidad de siembra determinada en el cuarto experimento, igualmente en células $/ \mathrm{mm}^{2}$ y divididos en dos grupos de 46 cajas c/u. A un grupo no se le hizo cambio de medio. A la otra mitad de las cajas, se realizó el cambio de medio a intervalos regulares de $45 \mathrm{~h}$. harvesting its content as it has already been described. Finally, cell pellets were resuspended in $300 \mu$ of complete medium and concentration and viability were determined, as previously stated; tabulating results as mean values.

Kinetics of $R F / 6 A$ cell line growth

Cells were expanded up to passage 551 . In the same way as the previous trial, enough cellular suspension was prepared for seeding 94 Petri dishes - dimension $35 \mathrm{~mm} \varnothing$ with the same passage, in volumes of $2000 \mu \mathrm{l} / \mathrm{dish}$, with seed density determined in the fourth trial, as well as in cells $/ \mathrm{mm}^{2}$ and divided into two groups of 46 dishes each. No cell culture media exchange was done to one group. Cell culture media exchange at regular intervals of $45 \mathrm{~h}$ were performed in the other half of the dishes. A pair of dishes from each group was randomly harvested each $15 \mathrm{~h}$ and until $345 \mathrm{~h}$ of initiating the culture, culture was processed according to the aforementioned for harvesting RF/6A cell line, resuspending cell pellet in $300 \mu$ of complete medium, determining its concentration and viability and tabulating results as mean values according to the stated.

\section{Doubling time determination}

Using data from earlier trials, doubling time formula was applied (DT), suggested by ATCC(17), which considers the log phase:

$$
\mathrm{DT}=\mathrm{T} \operatorname{In} 2 / \operatorname{In}(\mathrm{Xe} / \mathrm{Xb})
$$

Where $T=$ incubation period $=$ interval $[$ final $T-$ initial $T$ ] in hours; $X b=$ initial value of cell number; $\mathrm{Xe}=$ final value of cell number.

\section{RESULTS}

There were no contamination problems due to strict management of asepsis, antisepsis and sterilization of components used in the culture of both cell lines. The morphology observed under the phase contrast microscope was apparently normal. Cell number was determined by total count of live and dead cells. 
Aleatoriamente se cosecharon un par de cajas de cada grupo, cada 15 h y hasta las 345 h de iniciados los cultivos, procesando su contenido según lo señalado anteriormente para cosechar la línea $\mathrm{RF} / 6 \mathrm{~A}$, resuspendiendo el paquete celular en $300 \mu \mathrm{l}$ de medio completo $\mathrm{y}$ determinando su concentración y viabilidad, tabulando los resultados como valores promedio según lo mencionado.

Determinación del intervalo de duplicación

Con los datos de los dos experimentos anteriores, se aplicó la fórmula de intervalo de duplicación (DT) sugerida por el ATCC(17) que toma en consideración la fase de crecimiento logarítmico:

$$
\mathrm{DT}=\mathrm{T} \ln 2 / \ln (\mathrm{Xe} / \mathrm{Xb}),
$$

Donde $T=$ tiempo de incubación= intervalo $[T$ final - $T$ inicial] en horas; $X b=$ valor inicial del número de células; $\mathrm{Xe}=$ valor final del número de células.
Minimum seed initial dose for DH82 cell line This trial lasted $7 \mathrm{~d}$ from day zero, same time period that took the first treatment to reach $\geq 95 \%$ confluence, which corresponded to the one started with $5.0 \times 10^{5}$ cells, whose maximum average concentration reached $1.07 \times$ $10^{7}$ cells, a growth 20.4 times the initial concentration. The maximum average concentrations for the remaining treatments were: $4.5 \times 10^{6}, 2.49 \times 10^{6}$ and $7.38 \times 10^{5}$ cells, which is equivalent to a growth of 18 , 19.9 and 11.8 times, respectively, for cultures started with $2.5 \times 10^{5}, 1.25 \times 10^{5}$ and $6.25 \times$ $10^{4}$ cells/well. None of them demonstrated to be statistically significant. Table 1 shows values obtained for growth, standard deviations and upper and lower limits at 95\% confidence interval (CI95\%).

\section{Minimum seed initial dose for $R F / 6 A$}

The assay had a duration of $10 \mathrm{~d}$ in any of the two trials, in which the first phase of treatment 1

Cuadro 1. Valores obtenidos del ensayo para la determinación de dosis mínima inicial de la línea celular DH82

Table 1. Minimum seed initial dose values determined for the DH82 cell line

\begin{tabular}{lcccc}
\hline Treatments $^{*}$ & 1 & 2 & 3 & 4 \\
$\mathrm{n}$ & 4 & 4 & 4 & 4 \\
Initial count\$ & $5.00 \times 10^{5}$ & $2.50 \times 10^{5}$ & $1.25 \times 10^{5}$ & $6.25 \times 10^{4}$ \\
Final count & $1.07 \times 10^{7}$ & $4.75 \times 10^{6}$ & $2.61 \times 10^{6}$ & $8.00 \times 10^{5}$ \\
$\mathrm{SD}( \pm)$ & $9.82 \times 10^{6}$ & $3.82 \times 10^{6}$ & $2.69 \times 10^{6}$ & $8.46 \times 10^{5}$ \\
$\alpha^{* *}$ & 0.05 & 0.05 & 0.05 & 0.05 \\
$\mathrm{SE}( \pm)$ & $4.91 \times 10^{6}$ & $1.91 \times 106$ & $1.35 \times 10^{6}$ & $4.23 \times 10^{5}$ \\
Lower limit & $1.08 \times 10^{6}$ & $1.01 \times 10^{6}$ & $-2.73 \times 10^{4}$ & $-2.87 \times 10^{4}$ \\
Upper limit & $2.03 \times 10^{7}$ & $8.49 \times 10^{6}$ & $5.25 \times 10^{6}$ & $1.63 \times 10^{6}$ \\
Increment & $1.02 \times 10^{7}$ & $4.50 \times 10^{6}$ & $2.49 \times 10^{6}$ & $7.38 \times 10^{5}$ \\
Growth rate & 20.40 & 18.00 & 19.90 & 11.80 \\
Harvest\$§ & 7 & $\mathrm{NA}$ & $\mathrm{NA}$ & $\mathrm{NA}$ \\
\hline
\end{tabular}

* Started with $5.00 \times 10^{5}, 2.50 \times 10^{5}, 1.25 \times 10^{5}$ y $6.25 \times 10^{5}$ cells/well, respectively.

$\S$ Total cells/well.

$\dagger$ Average total cells/well.

$\mathrm{SD}=$ Standard deviation; $\mathrm{SE}=$ Standard error.

** Alpha value for $95 \%$ confidence interval.

$\S \S$ Day to reach $>95 \%$ confluence; NA= Not applicable. 


\section{RESULTADOS}

No se presentaron problemas por contaminación debido al estricto manejo de la asepsia, antisepsia y esterilidad de los componentes utilizados en el cultivo de ambas líneas celulares. La morfología observada al microscopio de contraste de fases fue aparentemente normal. El número de células se determinó por el conteo total de células vivas y muertas.

\section{Dosis mínima inicial de DH82}

Este experimento tuvo una duración de siete días a partir del día 0, mismo periodo que tuvo el primer tratamiento en llegar a $\geq 95 \%$ de confluencia, que correspondió al iniciado con $5.0 \times 10^{5}$ células; cuya concentración máxima promedio alcanzada fue $1.07 \times 10^{7}$ células, esto es un crecimiento de 20.4 veces la concentración inicial. Las concentraciones máxima promedio para los tratamientos restantes fueron: $4.5 \mathrm{x}$ $10^{6}, 2.49 \times 10^{6}$ y $7.38 \times 10^{5}$ células, lo que equivale a un crecimiento de $18,19.9$ y 11.8 and the second phase of treatment 5 reached $\geq 95 \%$ confluence. It was evident that there was a decrease in all first phase treatments. The biggest fall, represented by a reduction in cell number, occurred in treatment 1 , reaching a value of $-4.21 \times 10^{5}$ cells, followed by treatments 2,3 and 4 , with reductions of $1.7 \times$ $10^{5}, 5.8 \times 10^{4}$ and $4.5 \times 10^{3}$ total cells. These data, together with statistical variables are shown in Table 2.1. Cell harvesting in the first assay reached a total of $7.9,8.0,6.7$ and $5.8 \times$ $10^{4}$ average cells for treatments $1,2,3$ and 4, respectively. The second experimental phase implemented with lower cell concentration, gave positive results. The maximum cell concentration was obtained in treatment 8 , reaching on average $1.12 \times 10^{5}$ total cells. Treatments 7,5 and 6 followed the performance of the cell concentration, obtaining on average $1.03 \times 10^{5}$, $8.48 \times 10^{4}$ and $8.35 \times 10^{4}$ total cells. The $95 \% \mathrm{CI}$ together with the statistical evaluation, which did not result significant, are shown in Table 2.2.

Cuadro 2.1. Valores obtenidos del primer ensayo para la determinación de dosis mínima inicial de la línea celular RF/6A

Table 2.1. Minimum seed initial dose values determined for the RF/6A cell line in first assay

\begin{tabular}{lcccc}
\hline Treatments $^{*}$ & 1 & 2 & 3 & 4 \\
\hline $\mathrm{n}$ & 4 & 4 & 4 & 4 \\
Initial count§ & $5.00 \times 10^{5}$ & $2.50 \times 10^{5}$ & $1.25 \times 10^{5}$ & $6.25 \times 10^{4}$ \\
Final count & $7.90 \times 10^{4}$ & $8.00 \times 10^{4}$ & $6.70 \times 10^{4}$ & $5.80 \times 10^{4}$ \\
$\mathrm{SD}( \pm)$ & $6.29 \times 10^{4}$ & $8.23 \times 10^{4}$ & $5.29 \times 10^{4}$ & $4.59 \times 10^{4}$ \\
$\alpha^{* *}$ & 0.05 & 0.05 & 0.05 & 0.05 \\
$\mathrm{SE}( \pm)$ & $3.14 \times 10^{4}$ & $4.12 \times 10^{4}$ & $2.65 \times 10^{4}$ & $2.29 \times 10^{4}$ \\
Lower limit & $1.74 \times 10^{4}$ & $-6.54 \times 10^{2}$ & $1.52 \times 10^{4}$ & $1.30 \times 10^{4}$ \\
Upper limit & $1.41 \times 10^{5}$ & $1.61 \times 10^{5}$ & $1.19 \times 10^{5}$ & $1.03 \times 10^{5}$ \\
Increment & $-4.21 \times 10^{5}$ & $-1.70 \times 10^{5}$ & $-5.80 \times 10^{4}$ & $-4.50 \times 10^{3}$ \\
Growth rate & -0.84 & -0.68 & -0.46 & -0.07 \\
Harvest§§ & 10 & $\mathrm{NA}$ & $\mathrm{NA}$ & $\mathrm{NA}$ \\
\hline
\end{tabular}

* Started with $5.00 \times 10^{5}, 2.50 \times 10^{5}, 1.25 \times 10^{5}$ y $6.25 \times 10^{5}$ cells/well, respectively.

$\S$ Total cells/well.

$\dagger$ Average total cells/well.

$\mathrm{SD}=$ Standard deviation; $\mathrm{SE}=$ Standard error.

** Alpha value for $95 \%$ confidence interval.

$\S \S$ Day to reach > $95 \%$ confluence; NA= Not applicable. 
veces, respectivamente para los cultivos iniciados con $2.5 \times 10^{5}, 1.25 \times 10^{5}$ y $6.25 \times 10^{4}$ células/ pozo. Ninguno de ellos demostró ser estadísticamente significativo. En el Cuadro 1 se muestran los valores de crecimiento obtenidos, las desviaciones estándar y los límites superior e inferior del intervalo de confianza al $95 \%$ (IC95 \%).

\section{Dosis mínima inicial de $R F / 6 A$}

El ensayo tuvo una duración de 10 días en cualquiera de sus dos fases, en que el tratamiento 1 de la primera fase y el tratamiento 5 de la segunda fase, alcanzaron $\geq 95 \%$ de confluencia. Fue notorio que en todos los tratamientos de la primera fase, hubo un decremento. La mayor caída representada con una reducción del número de células se dio en el tratamiento 1 alcanzando un valor de $-4.21 \mathrm{x}$ $10^{5}$ células seguido de los tratamientos 2,3 y 4 con reducciones de $1.7 \times 10^{5}, 5.8 \times 10^{4} y$ $4.5 \times 10^{3}$ células totales. Estos datos, junto
Seed density for DH82 cell line

Fourteen days after culture started, the first well that reached $\geq 95 \%$ confluence corresponded to the inoculum of 40 cells $/ \mathrm{mm}^{2}$, followed by the inoculum of 20 cells $/ \mathrm{mm}^{2}$ on $\mathrm{d} 15 ; \mathrm{d} 16$ corresponded to the inoculum of 10 cells $/ \mathrm{mm}^{2}$ and the inoculum of 5 cells $/ \mathrm{mm}^{2}$ on $\mathrm{d} 17$. The highest average cell concentration at the moment of cell harvesting was obtained with the inoculum of 10 cells $/ \mathrm{mm}^{2}$, reaching a value of $3.46 \times 10^{6}$ on $\mathrm{d} 17$, followed by the inoculum started with 20 cells $/ \mathrm{mm}^{2}$ with $3.08 \times 10^{6}$ on $\mathrm{d} 15$, whereas for inocula of 40 and 5 cells $/ \mathrm{mm}^{2}$, counts of $2.9 \times 10^{6}$ were obtained in both on $\mathrm{d} 14$ and 17, respectively. The resulting values of this assay are shown in Table 3, where the standard error and $95 \%$ CI are sown, since the average values of each treatment resulted to be statistically non-significant.

Seed density for $R F / 6 A$

Cultures began to reach progressive confluence in direct relation to the inoculum density on

Cuadro 2.2. Valores obtenidos del segundo ensayo para la determinación de dosis mínima inicial de la línea celular RF/6A

Table 2.2. Minimum seed initial dose values determined for the RF/6A cell line in a second assay

\begin{tabular}{lcccc}
\hline Treatments $^{*}$ & 5 & 6 & 7 & 8 \\
\hline $\mathrm{n}$ & 4 & 4 & 4 & 4 \\
Initial count§ & $7.07 \times 10^{4}$ & $3.53 \times 10^{4}$ & $1.77 \times 10^{4}$ & $8.84 \times 10^{3}$ \\
Final count & $8.48 \times 10^{4}$ & $8.35 \times 10^{4}$ & $1.03 \times 10^{5}$ & $1.12 \times 10^{5}$ \\
$\mathrm{SE}( \pm)$ & $5.20 \times 10^{4}$ & $5.11 \times 10^{4}$ & $4.55 \times 10^{4}$ & $4.93 \times 10^{4}$ \\
$\alpha^{* *}$ & 0.05 & 0.05 & 0.05 & 0.05 \\
$\mathrm{SE}( \pm)$ & $2.60 \times 10^{4}$ & $2.55 \times 10^{4}$ & $2.27 \times 10^{4}$ & $2.46 \times 10^{4}$ \\
Lower limit & $3.39 \times 10^{4}$ & $3.34 \times 10^{4}$ & $5.81 \times 10^{4}$ & $6.34 \times 10^{4}$ \\
Upper limit & $1.36 \times 10^{5}$ & $1.34 \times 10^{5}$ & $1.47 \times 10^{5}$ & $1.60 \times 10^{5}$ \\
Increment & $1.41 \times 10^{4}$ & $4.81 \times 10^{4}$ & $8.50 \times 10^{4}$ & $1.03 \times 10^{5}$ \\
Growth ratio & 0.20 & 1.36 & 4.81 & 11.64 \\
Harvest§§ & 10 & $\mathrm{NA}$ & $\mathrm{NA}$ & $\mathrm{NA}$ \\
\hline
\end{tabular}

* Started with $7.07 \times 10^{4}, 3.53 \times 10^{4}, 1.77 \times 10^{4}$ y $8.84 \times 10^{3}$ cells/well, respectively.

$\S$ Total cells/well.

† Average total cells/well.

$\mathrm{SD}=$ Standard deviation; $\mathrm{SE}=$ Standard error .

** Alpha value for $95 \%$ confidence interval.

$\S \S$ Day to reach $>95 \%$ confluence; NA= Not applicable. 
con las variables estadísticas pueden observarse en el Cuadro 2.1. La cosecha en el primer ensayo, alcanzó un total de $7.9,8.0,6.7$ y 5.8 $\times 10^{4}$ células totales promedio, respectivamente para los tratamientos $1,2,3$ y 4 . La segunda fase experimental implementada con una concentración menor de células, arrojó resultados positivos. La máxima concentración celular obtenida fue con el tratamiento 8 , alcanzando un total de $1.12 \times 10^{5}$ células promedio. Siguieron en rendimiento, los tratamientos 7,5 y 6 , obteniendo respectivamente en promedio $1.03 \times 10^{5}, 8.48 \times 10^{4}$ y $8.35 \times 10^{4}$ células totales. El IC95 \% junto con la evaluación estadística, que no resultó significativa, aparecen en el Cuadro 2.2.

\section{Densidad de siembra de DH82}

A los 14 días de iniciado el cultivo se obtuvo el primer pozo que llegara a confluencia $\geq 95 \%$, que correspondió al inóculo de 40 células $/ \mathrm{mm}^{2}$, d $8,9,10$ and 11 , after culture of inocula of $40,20,10$ and 5 cells $/ \mathrm{mm}^{2}$ were initiated. The value of the maximum average cell concentration was $1.04 \times 10^{5}$ and it was obtained in the inoculum of 10 cells $/ \mathrm{mm}^{2}$; the minimum average value of $5.6 \times 10^{4}$ was obtained with 5 cells/ $\mathrm{mm}^{2}$, whereas the remaining inocula of 20 and 40 cells $/ \mathrm{mm}^{2}$ both reached, on average, the intermediate concentration of $9.3 \times 10^{4}$. As in the previous assay, the resulting values of this experiment, were statistically non-significant, as shown in Table 4.

\section{Kinetics of DH82 cell line growth}

This assay had a duration of $336 \mathrm{~h}$ or $14 \mathrm{~d}$. The lag or adaptation phase lasted $126 \mathrm{~h}$ in both groups. In the first, without cell culture media exchange, it reached an average cell concentration of 47,025; whereas in the second group, with a periodic cell culture media exchange, 59,875 total cells, equivalent to a

Cuadro 3. Valores obtenidos del ensayo para la determinación de densidad de siembra de la línea celular DH82

Table 3. Seed density values determined for the DH82 cell line

\begin{tabular}{lcccc}
\hline Treatments* $^{*}$ & 1 & 2 & 3 & 4 \\
\hline $\mathrm{N}$ & 4 & 4 & 4 & 4 \\
Initial count\$ & 5 & 10 & 20 & 40 \\
Final count & 16,602 & 19,577 & 17,435 & 16,926 \\
$\mathrm{SD}( \pm)$ & $1,124.52$ & $3,341.18$ & $5,650.17$ & $1,422.65$ \\
$\alpha^{* *}$ & 0.05 & 0.05 & 0.05 & 0.05 \\
$\mathrm{SE}( \pm)$ & 562.26 & $1,670.59$ & $2,825.09$ & 711.33 \\
Lower limit & $15,499.56$ & $16,302.64$ & $11,897.47$ & $15,531.36$ \\
Upper limit & $17,703.62$ & $22,851.36$ & $22,971.81$ & $18,319.76$ \\
Increment\$ & $16,596.59$ & $19,567.00$ & $17,414.64$ & $16,885.56$ \\
Growth ratio & $3,319.32$ & $1,956.70$ & 870.73 & 422.14 \\
Harvest ${ }^{\dagger}$ & 17 & 16 & 15 & 14 \\
\hline
\end{tabular}

* Started with $8.84 \times 10^{2}, 1.77 \times 10^{3}, 3.53 \times 10^{3}$ y $7.07 \times 10^{3}$ cells/well, respectively.

$\S$ Total cells/well.

$\dagger$ Average total cells/well.

$\mathrm{SD}=$ Standard deviation; $\mathrm{SE}=$ Standard error .

** Alpha value for $95 \%$ confidence interval.

$\S \S$ In number of cells $/ \mathrm{mm}^{2}$.

t† Day to reach $>95 \%$ confluence. 
Cuadro 4. Valores obtenidos del ensayo para la determinación de la densidad de siembra de la línea celular $\mathrm{RF} / 6 \mathrm{~A}$

Table 4. Seed density values determined for the RF/6A cell line

\begin{tabular}{lcccc}
\hline Treatments $^{*}$ & 1 & 2 & 3 & 4 \\
\hline $\mathrm{N}$ & 4 & 4 & 4 & 4 \\
Initial count\$ & 5 & 10 & 20 & 40 \\
Final count & 317 & 645 & 526 & 526 \\
$\mathrm{SD}( \pm)$ & 118.34 & 223.70 & 187.00 & 431.21 \\
$\alpha^{* \star}$ & 0.05 & 0.05 & 0.05 & 0.05 \\
$\mathrm{SE}( \pm)$ & 59.17 & 111.85 & 93.50 & 215.61 \\
Lower limit & 200.92 & 425.88 & 343.01 & 103.68 \\
Upper limit & 432.87 & 864.33 & 709.53 & 948.86 \\
Increment§§ & 311.89 & 635.11 & 506.27 & 486.27 \\
Growth ratio & 62.38 & 63.51 & 25.31 & 12.16 \\
Harvest $\dagger \dagger$ & 11 & 10 & 9 & 8 \\
\hline
\end{tabular}

* Started with $8.84 \times 10^{2}, 1.77 \times 10^{3}, 3.53 \times 10^{3}$ y $7.07 \times 10^{3}$ cells/well, respectively.

$\S$ Total cells/well.

$\dagger$ Average total cells/well.

$\mathrm{SD}=$ Standard deviation; SE $=$ Standard error.

** Alpha value for $95 \%$ confidence interval.

$\S \S$ In number of cells $/ \mathrm{mm}^{2}$.

†tDay to reach > $95 \%$ confluence.

seguido del inóculo de 20 células $/ \mathrm{mm}^{2}$ en el día 15; el día 16 lo fue para el inóculo de 10 células $/ \mathrm{mm}^{2}$ y el de 5 células/mm², el día 17. La mayor concentración celular promedio, al momento de la cosecha se obtuvo con el inóculo de 10 células $/ \mathrm{mm}^{2}$ alcanzando un valor de 3.46 x $10^{6}$ al día 17, seguido del inóculo iniciado con 20 células $/ \mathrm{mm}^{2}$ con $3.08 \times 10^{6}$ al día 15 , mientras que para los inóculos de 40 y 5 células/ $\mathrm{mm}^{2}$ se obtuvieron cuentas de $2.9 \times 10^{6}$ en ambos, a los 14 y 17 días respectivamente. Los valores resultantes de este experimento se resumen en el Cuadro 3, en el que aparecen el error estándar y el IC al 95\%, ya que los valores promedio de cada tratamiento resultaron ser no significativos estadísticamente.

Densidad de siembra de RF/6A

Los cultivos fueron alcanzando confluencia progresivamente en relación directa a la densidad del inóculo, en los días 8, 9, 10 y 11 density of 49 and 62 cells $/ \mathrm{mm}^{2}$, respectively. Log phase lasted until $315 \mathrm{~h}$ with a value of maximum average cell concentration of 538250 cells per well in the group without cell culture media exchange; but in the second one, the log phase lasted up to $336 \mathrm{~h}$, when a maximum average cell concentration reached $1.77 \times 10^{6}$ (1'774,750 cells) and the assay was finished. Maximum densities reached were 559 and 1,845 cells $/ \mathrm{mm}^{2}$ for treatments with and without cell culture media exchange. Figure 1 shows growth differences between both groups, as well as the log phase and time in culture medium.

Kinetics of $R F / 6 A$ cell line growth

This assay lasted $345 \mathrm{~h}$, a little bit more than $14 \mathrm{~d}$. For both treatments, with or without cell culture media exchange, the adaptation period had a duration of $90 \mathrm{~h}$, from which log phase was observed. This was mild in the first case, reaching its maximum average value of $8.4 \times$ 
Figura 1. Crecimiento celular comparativo de la línea celular DH82 de origen canino, con y sin cambio de medio de cultivo, habiendo iniciado el día $0^{*}$

Figure 1. Comparative cell growth of DH82 cell line of canine origin, with or without cell culture media exchange, having started on day $0^{*}$

\section{DH82 Line}

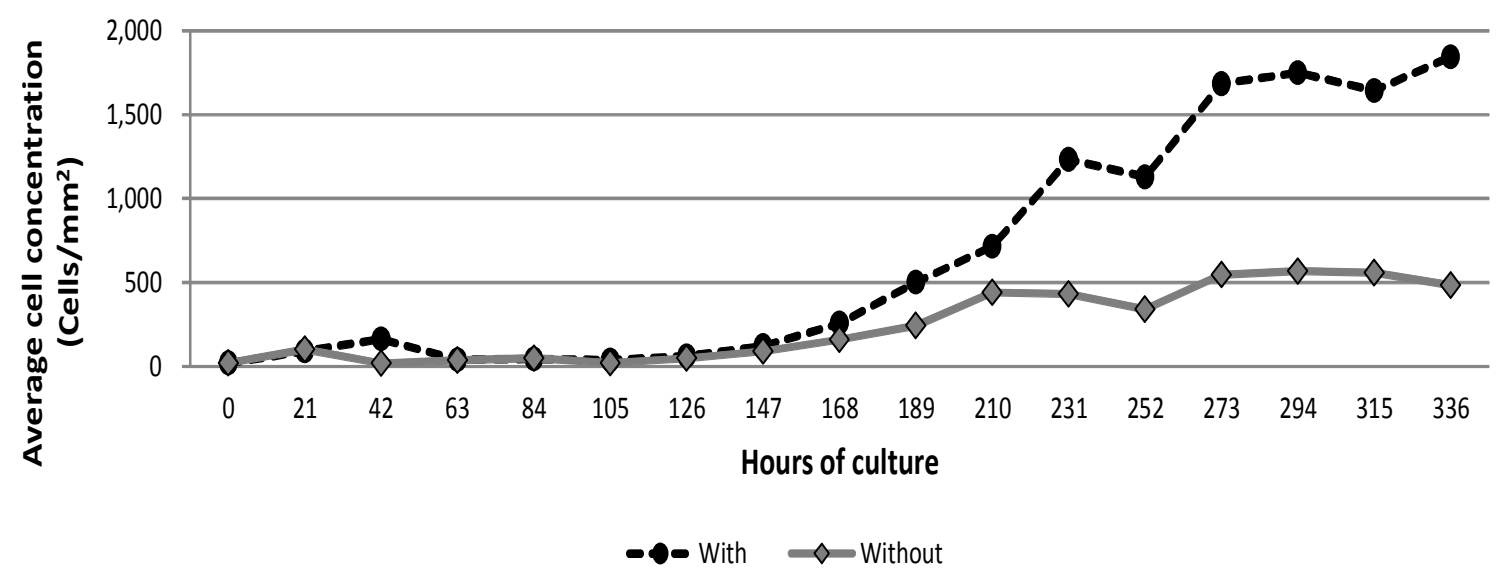

${ }^{*}$ Cultures started with a density of 20 cells $/ \mathrm{mm}^{2}$. Maintained in minimum essential medium (Eagle formulation), with $2.0 \mathrm{mM}$ L-glutamine supplemented with $1.0 \mathrm{mM}$ sodium pyruvate, $1.5 \mathrm{~g} / \mathrm{l}$ of $\mathrm{NaHCO}_{3}$ and $15 \%(\mathrm{v} / \mathrm{v})$ inactivated fetal bovine serum at $56{ }^{\circ} \mathrm{C}$. Cell culture media was exchanged every $63 \mathrm{~h}$. The exponential growth time period occurred between 126 and $336 \mathrm{~h}$ after culture.

después del inicio del cultivo a los inóculos de $40,20,10$ y 5 células $/ \mathrm{mm}^{2}$. El valor de concentración celular máxima promedio fue de $1.04 \times 10^{5}$ y se obtuvo en el inóculo 10 células/ $\mathrm{mm}^{2}$; el valor mínimo promedio de $5.6 \times 10^{4}$ se obtuvo con 5 células $/ \mathrm{mm}^{2}$, mientras que los inóculos restantes de 20 y 40 células $/ \mathrm{mm}^{2}$, alcanzaron ambos la concentración intermedia de $9.3 \times 10^{4}$ en promedio. Como en el experimento anterior, los valores resultantes de este experimento, mismos que resultaron ser estadísticamente no significativos se resumen en el Cuadro 4.

\section{Cinética de crecimiento DH82}

Este experimento tuvo una duración de $336 \mathrm{~h}$ - 14 días. La fase de latencia o adaptación tuvo una duración de $126 \mathrm{~h}$ en ambos grupos. En el primero sin cambio de medio, alcanzó una concentración celular promedio de 47,025; mientras que en el segundo grupo, con cambio de medio periódico, 59,875 células totales,
$10^{4}$ (83,950 cells) after 300 h culture started, equivalent to an average density of 87 cells/ $\mathrm{mm}^{2}$. In a similar way, the second treatment reached its maximum value after $315 \mathrm{~h}$ with a maximum average concentration of $6.52 \times$ $10^{5}$ (651,600 cells), equivalent to an average density of 677 cells $/ \mathrm{mm}^{2}$. Further measures revealed gradual decrease in cell number. Figure 2 shows growth differences between both groups, as well as log phase and time in culture medium.

\section{Doubling time}

Based on data obtained from our experiments, results were tabulated, and shown in Table 5, as follows:

DT DH82 = $42.95 \mathrm{~h}$, equivalent to $42 \mathrm{~h} 56^{\prime}$ real-time.

DT $R F / 6 A=37.00 h$, equivalent to 36 h 59' real-time. 
Figura 2. Crecimiento celular comparativo de la línea celular RF/6A de origen mono Rhesus con y sin cambio de medio de cultivo habiendo iniciado el día $0^{*}$

Figure 2. Comparative cell growth of RF/6a cell line derived from Rhesus monkey, with or without cell culture media exchange, having started on day $0^{*}$

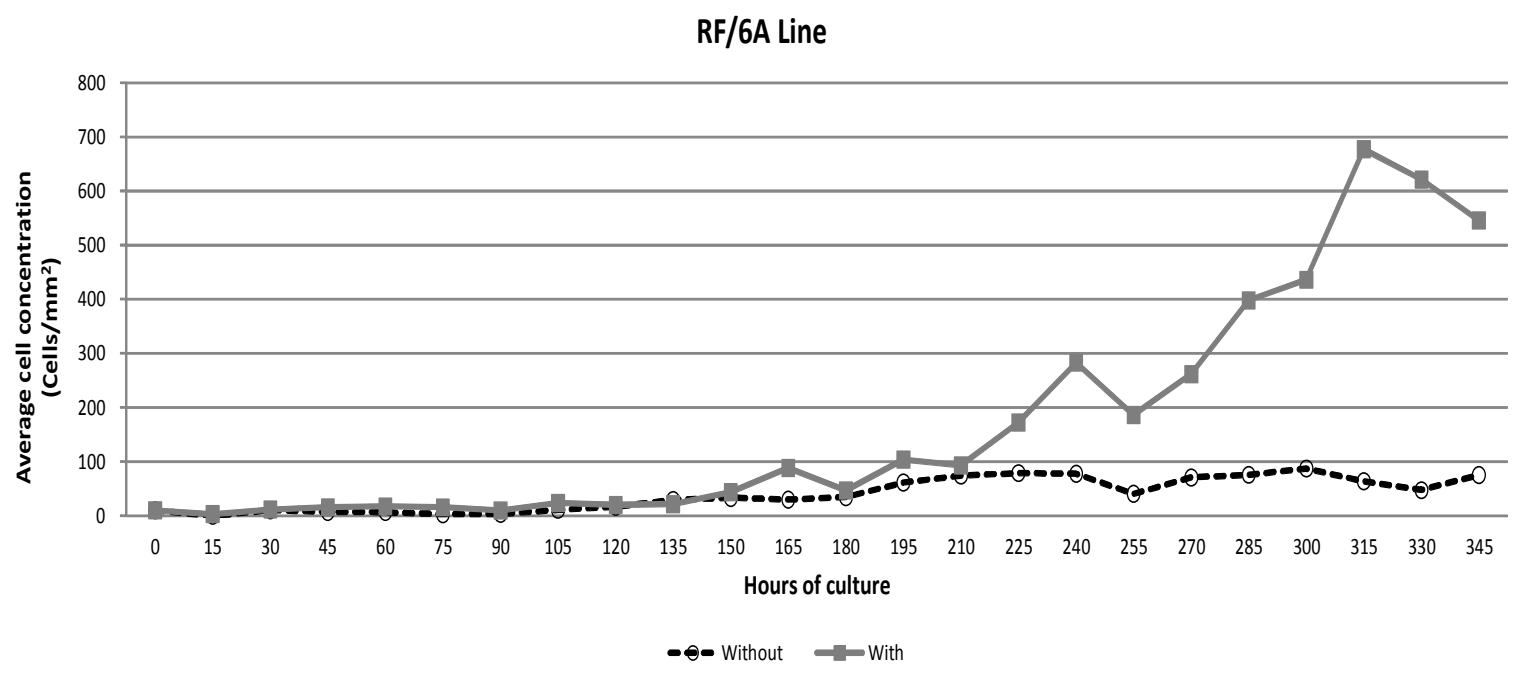

* Cell cultures started with a density of 10 cells $/ \mathrm{mm}^{2}$. Maintained in minimum essential medium (Eagle formulation), with 2.0 mM L-glutamine supplemented with $1.0 \mathrm{mM}$ sodium pyruvate, $1.5 \mathrm{~g} / \mathrm{l}$ of $\mathrm{NaHCO}_{3}$ and $10 \%(\mathrm{v} / \mathrm{v}$ ) fetal bovine serum. Cell culture media was exchanged every $45 \mathrm{~h}$. The exponential growth time period occurred between 90 and 315 hours after culture.

equivalentes a una densidad de 49 y 62 células/ $\mathrm{mm}^{2}$, respectivamente. El crecimiento logarítmico duró hasta las $315 \mathrm{~h}$ con un valor de concentración celular promedio máxima de 538,250 células por pozo en el grupo sin cambio de medio; pero en el segundo, la fase logarítmica continuó hasta las 336 h, cuando se alcanzó una concentración celular máxima promedio de 1.77 x $10^{6}$ (1'774,750 células) y se dio por terminado el experimento. Las densidades máximas alcanzadas fueron de 559 y 1,845 células $/ \mathrm{mm}^{2}$ para los tratamientos sin y con cambio de medio. La Figura 1 ilustra las diferencias de crecimiento entre los dos grupos, así como la fase logarítmica y el tiempo en cultivo.

\section{Cinética de crecimiento $R F / 6 A$}

Este experimento tuvo una duración de 345 h, un poco más de 14 días. Para ambos tratamientos, sin y con cambio de medio, el intervalo de adaptación tuvo una duración de 90 h, a partir del cual se observó el crecimiento

\section{DISCUSSION}

Characteristics and properties of DH82 cell line of canine origin and RF/6A line, derived from Rhesus monkey, were defined. Additionally, both lines behaved very different from each other, which increases the value of this study by highlighting their inequality. This is to be expected, since DH82 is myeloid origin, monocyte-macrophage type $(6,7)$, in contrast to $\mathrm{RF} / 6 \mathrm{~A}$ which is endothelial type $(2,5)$.

For the first DH82 cell line assay, a first dose of $5.0 \times 10^{5}$ cells was established, which is two times less than $1.0 \times 10^{6}$, with which cultures are traditionally started in $25 \mathrm{~cm}^{2}$ flasks at the laboratory. For the determination of a dose of $6.25 \times 10^{4}$, it was established that cell cultures can be started even at doses 16 times lower. Moreover, cultures started in flasks with the highest dose of $1.0 \times 10^{6}$ have a density of 400 cells per unit area $\left(\mathrm{mm}^{2}\right)$; in contrast, the ones that are started with a lower dose of $6.24 \times 10^{4}$, the 
Cuadro 5. Valores del desarrollo celular de ambas líneas, empleadas en la fórmula para la determinación del intervalo de duplicación (DT)§ [16]

Table 5. Cell development values of both cell lines, used in the doubling time (DT) determination formulae [16]

\begin{tabular}{|c|c|c|c|c|c|c|c|}
\hline \multirow[b]{2}{*}{ Cell line } & \multicolumn{3}{|c|}{ Time (h) } & \multicolumn{2}{|c|}{ Cell density $\varphi$} & \multirow{2}{*}{$\frac{\text { Doubling time }}{\text { (DT) }}$} & \multirow[b]{2}{*}{ Real time } \\
\hline & |nitial| & Final§§ & Total & $(\mathrm{Xb})$ Initial & (Xe) Final & & \\
\hline $\mathrm{DH} 82^{\Psi}$ & 126 & 336 & 210 & 62 & 1,845 & 42.95 & $42 \mathrm{~h} 56^{\prime}$ \\
\hline $\mathrm{RF} / 6 \mathrm{~A}^{* *}$ & 90 & 315 & 225 & $10^{*}$ & 677 & 37.00 & 36h59' \\
\hline
\end{tabular}

$\S \mathrm{DT}=\mathrm{T} \ln 2 / \ln (\mathrm{Xe} / \mathrm{Xb})$.

$\varphi=$ Cells $/ \mathrm{mm}^{2}$.

* Time; hours of culture when log phase initiated.

$\S \S$ Time; hours of culture when log phase ended.

$\Psi$ Isolated canine cell line (Canis lupus familiaris).

** Derived from Rhesus monkey fetus (Macaca mulatta).

logarítmico. Éste fue muy leve en el primer caso, alcanzando su valor máximo promedio de 8.4 x $10^{4}$ (83,950 células) a las $300 \mathrm{~h}$ de iniciado el cultivo; equivalentes a una densidad promedio de 87 células $/ \mathrm{mm}^{2}$. En forma similar, el segundo tratamiento alcanzó su valor máximo a las $315 \mathrm{~h}$ con una concentración máxima promedio de $6.52 \times 10^{5}$ (651,600 células) equivalentes a una densidad promedio de 677 células $/ \mathrm{mm}^{2}$. Mediciones posteriores, revelaron una disminución paulatina en el número de células. En la Figura 2 se ilustran las diferencias de crecimiento entre los dos grupos, así como la fase logarítmica y el tiempo en cultivo.

\section{Intervalo de duplicación}

Con base en los datos obtenidos de los dos experimentos anteriores, se tabularon los resultados, como se muestra en el Cuadro 5, quedando como sigue:

DT $\mathrm{DH} 82=42.95 \mathrm{~h}$ equivalentes en tiempo real a 42 h 56 '.

DT $R F / 6 A=37.00 \mathrm{~h}$ equivalentes en tiempo real a 36 h 59'.

\section{DISCUSIÓN}

Se cubrió la expectativa de definir características y propiedades de cultivo de las líneas celulares density is 354 cells per unit area, which is not a great difference; but that is not indicative of the advantage for initiating cultures with comparatively high doses. This led to the conclusion that cell lines, once adapted to laboratory conditions, should be started based on a density determination, which will indicate the dose to be used independently of the container size.

Although in the case of RF/6A cell line, whose initial assay had the same expectation as the earlier trial, the results were very different. First of all, the concentrations previously defined and considered high, resulted in limited assay conditions and that is why none of the established treatments managed to increase their values; on the contrary, they decreased. According to these results, the second phase was defined, reducing even more the total initial cell concentration to just over 141 times. This result proves that for this cell lineage, the initial dose of seeding inoculum can start from smaller quantities than the traditionally recommended. Likewise, in this assay it is shown that possibly large amounts of inoculum failed to adapt under culture conditions, which can be associated with lack of nutrients, enough to satisfy requirements for the total population. Although this should rather be referred to some key nutrient at the moment of adhesion to the container walls. It should be remembered that the selection 
DH82 de origen canino y la línea RF/6A, derivada de un mono Rhesus. Aunado a ello, ambas líneas se comportaron de manera muy diferente entre sí, lo que incrementa el valor de este trabajo, al destacar sus desigualdades. Esto es conforme a lo esperado, ya que DH82 es de origen mieloide, tipo monocito-macrófago(6,7), en contraste con RF/6A que es de tipo endotelial $(2,5)$.

Para el primer experimento con la línea $\mathrm{DH} 82$, se estableció una primera dosis de $5.0 \times 10^{5}$ células, que es dos veces menor a la de $1.0 \mathrm{x}$ $10^{6}$ con la que tradicionalmente se inician cultivos en botellas de $25 \mathrm{~cm}^{2}$ en nuestro laboratorio. Con la determinación de la dosis de $6.25 \times 10^{4}$, se resolvió que se pueden iniciar cultivos aún a dosis que son 16 veces menores. Es más, los cultivos que se inician en botellas de cultivo con la dosis mayor $1.0 \times 10^{6}$, tiene una densidad de 400 células por unidad de superficie $\left(\mathrm{mm}^{2}\right)$; en contraste las que se inician con la dosis menor $6.24 \times 10^{4}$ la densidad es de 354 células por unidad de superficie, lo que no es en sí, una gran diferencia. Ello tampoco es indicativo de la ventaja de iniciar cultivos con dosis tan altas, comparativamente. Ello condujo a definir que las líneas celulares, una vez adaptadas a las condiciones del laboratorio, los cultivos deberán iniciarse con base en una determinación de su densidad, la cual indicará la dosis a utilizar independientemente del tamaño del contenedor.

Aunque en el caso de la línea celular RF/6A, cuyo experimento inicial tenía las mismas expectativas del ensayo anterior, los resultados resultaron ser muy diferentes. Para empezar las concentraciones antes definidas y consideradas altas, resultaron ser limitativas, para las condiciones ensayadas, y es por ello que ninguno de los tratamientos establecidos consiguió incrementar sus valores, al contrario, disminuyeron. Con esos resultados, entonces se definió la segunda fase, reduciendo aún más la concentración celular inicial total, hasta poco más de 141 veces. Con ese resultado se comprueba que para esta estirpe celular, la dosis criterion to define the end of the experiment is almost complete confluence. This is a subjective visual measurement and it will not always give the same results, specifically based on its degree of subjectivity. Areas near the border of the wells seemed not to have same cell density, in comparison to the central areas, where cells appeared to have more contact between them and more uniform in appearance. As a disparity reflex, the reported by Kasai et $a(18)$ and Shen et al was performed, using $4.8 \times 10^{3}$ and $1.0 \times$ $10^{5}$ cells per well, in 96-well plates to start RF/6A cell culture, respectively. This represents a difference, with respect to each other, of 20 times the concentration. As a result of this, the reliability of the results is in doubt, because at the moment of starting the cultures with high cell concentrations, these conglomerations will be sub-optimal for a cell-based assay, because instead of growing and multiplying, their concentration decreases.

Based on the experience of the previous assays, seed density trials were designed, initially aiming at determining whether the closeness of the cells to each other could be a conditioning factor for their growth. The initial concentration of $1.0 \times$ $10^{6}$ cells in culture flasks surface area $25 \mathrm{~cm}^{2}$, is equivalent to a density of 400 cells $/ \mathrm{mm}^{2}$. So the following pair of trials would be started with quantities varying from 80 times less, which means 5 cells $/ \mathrm{mm}^{2}$, recorded as treatment 1 , up to 10 times less, which is equivalent to 40 cells $/ \mathrm{mm}^{2}$, described as treatment 4 . For the case of DH82 line, it was found that the maximum growth values reached, in each of the treatments, were not statistically different between them, which is interpreted as uniform but not equal. Partly because the subjective criterion of confluence for their harvesting coincided in all cases with the discrepancy of interval that corresponds to the incubation period that was indeed different.

With respect to seed density of RF/6A cell line results were discordant with the canine origin line. Values were much lower, both in cell 
inicial de inóculo de siembra puede partir de cantidades menores a las recomendadas tradicionalmente. Igualmente en este experimento se refleja que posiblemente cantidades de inóculo tan grandes, fallen en su adaptación a las condiciones de cultivo, que pudiesen estar asociadas a una insuficiencia de nutrientes para satisfacer a la totalidad de la población. Aunque esto más bien debería referirse a algún nutriente clave para el momento del adosamiento o anclaje a la pared del contenedor. Cabe recordar que el criterio de elección para definir el término del experimento es la confluencia casi total. Ello es una medida subjetiva visual y no siempre arrojará los mismos resultados, basados precisamente en su grado de subjetividad. Áreas cercanas a los bordes de los pozos, parecían no tener la misma densidad celular, en comparación con las áreas centrales, en las que las células aparecen con mayor contacto entre sí, y más uniformes en apariencia. Como reflejo de la disparidad, tomamos lo indicado por Kasai et $a(18)$ y Shen et a(19), quienes utilizaron $4.8 \times 10^{3}$ y $1.0 \times 10^{5}$ células por pozo, en placas de 96 pozos, para iniciar cultivo con la línea celular $\mathrm{RF} / 6 \mathrm{~A}$, respectivamente. Ello representa una diferencia entre sí de 20 veces la concentración. Derivado de lo anterior, queda la duda de la confiabilidad de esos resultados, ya que al iniciar cultivos con altas concentraciones celulares, estas conglomeraciones no serán óptimas para un ensayo celular, pues en lugar de estar creciendo y multiplicándose, su concentración está disminuyendo.

Con base en la experiencia de los ensayos previos, se diseñaron los experimentos de densidad de siembra, en principio orientados a dilucidar si la cercanía entre sí de las células, pudiera ser una condicionante para su desarrollo. La concentración inicial de $1.0 \times 10^{6}$ células en botellas de cultivo de $25 \mathrm{~cm}^{2}$, equivale a una densidad de 400 células $/ \mathrm{mm}^{2}$. Así que para el siguiente par de experimentos se iniciarían con cantidades que variaban desde 80 veces menos, esto es 5 células $/ \mathrm{mm}^{2}$, anotado como tratamiento 1 ; hasta 10 veces menos, lo que es igual a 40 performance and the required interval to reach confluence. A simple explanation is that the size of the cells tended to be greater, indicated by the density obtained, that in no case it was on average higher than $645 \mathrm{cell} / \mathrm{s} / \mathrm{mm}^{2}$. Likewise, they reached confluence in shorter incubation intervals, because the maximum value reached was $11 \mathrm{~d}$. The average growth differs with the inoculum of 5 cells $/ \mathrm{mm}^{2}$, although the obtained with the other three treatments is not statistically significant. Considering, as a simple explanation, the necessity of cell proximity, being a cell line of epithelial origin, it would be easier to understand that it is a tissue that requires a certain degree of organization and structure to operate efficiently $(17,18)$, speculating that the communication between cells is favored by being physically closer together. Monocytes/ macrophages expressed in DH82 cell line tend to function individually and cell-cell interactions are rather with other cell lineages, as antigenpresenting cells would be in the immune response. However, this study does not pretend to compare cell lines used, but rather discover differences with the aim to find their properties.

Kinetic assay of DH82 cell line was based on the use of specific cell density of 20 cells $/ \mathrm{mm}^{2}$, which was associated with certain expectations, foreseen beforehand, in terms of reaching the expected confluence after $15 \mathrm{~d}$ in culture. This would confirm our speculation of obtaining a pre-established growth, independently of the container's size. The intermediate sampling interval of $21 \mathrm{~h}$ was based on an arithmetic estimation of generation time, according to the data calculated (not shown) in the first assay; and based on that estimation, cell culture media exchange was proposed every $63 \mathrm{~h}$, which is three times that period of time. In compliance with the premise of reaching confluence after $15 \mathrm{~d}$, representing $360 \mathrm{~h}$ in culture and having fallen short for one day, since biological material prepared for it ran out. The individual observation of the graphs allows to distinguish 
células $/ \mathrm{mm}^{2}$, descrito como tratamiento 4 . Para el caso de la línea DH82 se encontró que los valores máximos de crecimiento alcanzados en cada uno de los tratamientos no son diferentes estadísticamente entre sí, lo que se interpreta como que fueron uniformes aunque no iguales. En parte, porque el criterio subjetivo de confluencia para su cosecha, fue coincidente en todos los casos, con la discrepancia del intervalo que corresponde al tiempo de incubación, que sí fue diferente.

En lo que respecta a la densidad de siembra de la línea RF/6A los resultados fueron discordantes con los de la línea celular de origen canino. Los valores fueron mucho menores, tanto en rendimiento celular, como en el intervalo requerido para alcanzar la confluencia. Una explicación simple es que el tamaño de las células tiende a ser mayor, indicado por la densidad obtenida, que en ningún caso fue en promedio mayor a las 645 células $/ \mathrm{mm}^{2}$. De la misma manera, alcanzaron confluencia en intervalos de incubación más cortos, pues el máximo valor alcanzado fue de 11 días. El crecimiento promedio alcanzado con el inóculo de 5 células $/ \mathrm{mm}^{2}$ difiere, aunque no es estadísticamente significativo del obtenido con los otros tres tratamientos. Considerando, como explicación igualmente sencilla, la necesidad de proximidad en las células, ya que esta línea es de origen endotelial, lo que contribuiría a pensar que es un tejido que requiere cierto grado de organización y estructura, para operar eficientemente $(17,18)$, especulando que la comunicación entre las células se favorece por estar más cercanas entre sí, físicamente. Los monocitos-macrófagos, que se expresan en la línea celular DH82, tienden a operar en forma individual, y sus interacciones célula-célula son más bien con otras estirpes celulares, como lo serían células presentadoras de antígeno en la respuesta inmune. Sin embargo, este trabajo no pretende comparar las líneas celulares utilizadas, sino descubrir sus diferencias para encontrar sus propiedades.

Los experimentos de cinética de la línea DH82 se basaron en el uso de una densidad celular that the adaptation time period coincided between both treatments, only highlighting the log phase, while it decreased in the group without culture media exchange, the same did not occurred in the group with cell cultured media exchange, which would appear to be growing although not in the same reproductive rate.

Following the same reasoning for the kinetic assay for the development of $\mathrm{RF} / 6 \mathrm{~A}$ line derived from Rhesus macaque, initial seed density of $10 \mathrm{cell} / \mathrm{sm} \mathrm{mm}^{2}$ was established to reach the expected confluence after $10 \mathrm{~d}$ or $240 \mathrm{~h}$, independently of the size of the container. As in the previous assay, the interval of $30 \mathrm{~h}$ was calculated (data not shown), which corresponds to a generation time period, based on data obtained in the second phase of the initial seeding dose assay. Samplings were programmed every $15 \mathrm{~h}$, considering it as half of the time between generations. For cell culture media exchange, the interval of $45 \mathrm{~h}$ was considered, 1.5 times the calculated for the generation time period, but very similar to the $48 \mathrm{~h}$ used in continuous cultures and previous assays. Now, the experience was different, since cell growth exceeded the expected time period of $10 \mathrm{~d}$ by extending the log phase up to $315 \mathrm{~h}$, equivalent to $13.125 \mathrm{~d}$. Cell density reached at that date was 677 cells $/ \mathrm{mm}^{2}$, similar or closer to 645 cells $/ \mathrm{mm}^{2}$ obtained in the seed density assay after $10 \mathrm{~d}$. This phenomenon is biologically compatible with the functionality of the cell line, considering that it is not likely that only one layer is formed but several layers will pile up, characteristic of the tissue from where this cell line derived(8).

It is globally accepted that in every cell culture there are adaptation and log phase time periods( 1 ). One point this paper emphasizes is that in both cell lines these assays have demonstrated a similar behavior on what the adaptation time period refers to, regardless of whether or not they received fresh media culture, the intervals coincide, since the ups and downs shown (data not shown) at the 
específica de 20 células $/ \mathrm{mm}^{2}$, que estaba asociada a una expectativa determinada, en términos de alcanzar la confluencia esperada en un plazo de 15 días, previsto de antemano. Ello confirmaría lo especulado de obtener un crecimiento preestablecido, sin importar el tamaño del contenedor. El intervalo de muestreos intermedio cada $21 \mathrm{~h}$ se basó en una estimación aritmética de periodo generacional, según los datos calculados (no mostrados) del primer ensayo; y, con base en esa estimación se propuso el recambio de medio cada $63 \mathrm{~h}$, que es tres veces ese periodo. El cumplimiento de la premisa de alcanzar confluencia a los 15 días, representaba 360 h en cultivo, habiendo quedado cortos por un día, cuando se agotó el material biológico dispuesto para ello. La observación individual de los gráficos permite distinguir que el periodo de adaptación fue coincidente entre ambos tratamientos, sólo destacando la fase de crecimiento logarítmico, que mientras en el grupo sin recambio de medio, fue declinando, no sucedió lo mismo, para el grupo con cambio de medio, que pareciera seguir creciendo aunque ya no a la misma tasa reproductiva.

Siguiendo el mismo raciocinio para el ensayo de la cinética de desarrollo de la línea RF/6A derivada del mono Rhesus, se estableció como densidad inicial de siembra 10 células $/ \mathrm{mm}^{2}$, para alcanzar la confluencia esperada a los 10 días o $240 \mathrm{~h}$, igualmente independientemente del tamaño del contenedor. Como en el ensayo previo, se calculó (datos no mostrados) el intervalo de $30 \mathrm{~h}$, que corresponde al periodo de una generación, con base en los datos obtenidos en la segunda fase del experimento de dosis inicial de siembra. Los muestreos se programaron cada $15 \mathrm{~h}$, considerando como la mitad del tiempo entre generaciones. Para el recambio de medio, se consideró el intervalo de 45 h, 1.5 veces el calculado para el periodo generacional, pero muy similar al de $48 \mathrm{~h}$ empleado en cultivos continuos y experimentos previos. Ahora, la experiencia resultó diferente, puesto que el crecimiento celular rebasó el periodo esperado de 10 días, al extenderse la beginning of the previous cultures, on the definition of intervals confirm this.

The results of the DT determination were surprising, because they give the appearance of being too high. The DT for DH82 of almost $43 \mathrm{~h}$, as well as $37 \mathrm{~h}$ for RF/6A seem to coincide given the culture conditions used. Likewise, they differ from the initially calculated doubling time periods of 21 and $30 \mathrm{~h}$, respectively. This verified information could give rise to studies for decreasing or even increasing its efficiency, using new culture medium formulations. MEM is one of the most commonly used of all cell culture media; it has a very simple formulation, compared to the components of other media chemically defined, such as Medium 199 or RPMI 1640 , commercially available, for which it would be interesting to perform assays to identify some growth-restricting components.

Indirect inference obtained by preparation and staining of imprints (data not shown) allows to assert that cells from $R F / 6 A$ lineage are polymorphic, in contrast to the description of cells reported by Luna Castro et al(14), who mentioned that RF/6A cells present a mosaic shape. Additionally, it was observed that cells from this cell lineage show different sizes. Nonetheless, cells in general are very big, in comparison with other cell lines, such as BUVEC $\mathrm{E}_{6} \mathrm{E}_{7}(15,20)$ and $\mathrm{DH}_{82}(7,8)$, cell lines that are uniform in shape and have an inferior size, in contrast to RF/6A cell line.

\section{CONCLUSIONS AND IMPLICATIONS}

Data obtained allowed to generate a cell culture pattern model for further studies. In this way it will be more practical and simple to predict times and dates, for eventually obtaining cell cultures with high degree of confluence on a particular day. Equally relevant is the finding of cell cultures that have little growth when they are started with large number of cells, in contrast to the widespread view that cell cultures should be started with the largest number of cells as possible. 
fase de crecimiento logarítmico hasta las 315 h, equivalente a 13.125 días. La densidad celular alcanzada en esa fecha fue de 677 células/ $\mathrm{mm}^{2}$, cantidad similar o cercana a los 645 células $/ \mathrm{mm}^{2}$ obtenidas en el ensayo de densidad de siembra a los 10 días. Este fenómeno es biológicamente compatible con la funcionalidad de la línea celular, considerando que posiblemente no se forme una sola capa, sino un poliestrato; característica ésta, del tejido de donde se derivó esta línea celular(8).

Es universalmente aceptado que en todo cultivo celular existen los periodos de adaptación y de crecimiento logarítmico(1). Este estudio destaca que ambas líneas celulares hayan mostrado un comportamiento similar en lo que al periodo de adaptación se refiere, pues independientemente de que hayan recibido o no, medio de cultivo fresco, los intervalos coinciden, ya que los altibajos mostrados (datos no presentados) al principio de los cultivos previos, a la definición del intervalo, así lo confirman.

Los resultados de determinación del DT resultaron sorprendentes, pues dan la apariencia de ser muy altos. El DT para DH82 de casi $43 \mathrm{~h}$, así como el de $37 \mathrm{~h}$ para RF/6A, parecen ser coincidentes dadas las condiciones de cultivo empleadas. Igualmente difieren de los periodos de duplicación de 21 y 30 h respectivamente, calculados inicialmente. Con esta información verificada se daría pie a estudios para disminuirlos e inclusive incrementar su eficiencia, mediante el ensayo con nuevas fórmulas de medios de cultivo. El medio utilizado, MEM, es de los que tiene la formulación más sencilla, comparados con los componentes de otros medios químicamente definidos, como el Medio 199 o el RPMI 1640, accesibles comercialmente; por lo que sería hasta deseable realizar los ensayos para identificar algunos componentes que pudieran ser limitantes para su crecimiento.

Inferencias indirectas obtenidas mediante la obtención y tinción de improntas (datos no presentados), permiten aseverar que las células de la estirpe RF/6A son polimórficas; en

\section{ACKNOWLEDGEMENT}

Special thanks to INIFAP-Recursos fiscales for the financing of Project No. 14531319812.

End of english version

contraste a la descripción de las células reportada por Luna Castro et al.(14), quienes mencionan que las células RF/6A presentan formas de "mosaico". Adicionalmente se observó, que las células de esta línea celular muestran diversos tamaños. No obstante, las células en general son muy grandes, en comparación con otras líneas celulares, como lo son $\operatorname{BUVEC~} \mathrm{E}_{6} \mathrm{E}_{7}(15,20)$ y $\mathrm{DH} 82(7,8)$, mismas que tienen una forma uniforme $y$ un tamaño inferior al de las células de la línea RF/6A.

\section{CONCLUSIONES E IMPLICACIONES}

Los datos obtenidos permitieron generar un modelo patrón de cultivo, para estudios futuros. De esta manera será más práctico y sencillo, el predecir tiempos y fechas, eventualmente para obtener cultivos con alto grado de confluencia en un día determinado. Igualmente relevante es el hallazgo de cultivos celulares que tienen poco crecimiento cuando se inician con cantidades grandes de células, en contraste con la opinión generalizada de iniciar con el mayor número posible de células.

\section{AGRADECIMIENTOS}

Financiado por: INIFAP - Recursos Fiscales, Proyecto No. 14531319812

\section{LITERATURA CITADA}

1. Cossío BR, Rojas MC, Miranda ME, Álvarez MJA, Figueroa MJV, Vega YMCA. Cultivo in vitro de células animales y sus 
aplicaciones. $1^{\mathrm{a}}$ ed. Morelos, México: CENID-PAVET / INIFAP; 2011.

2. Lou D, Hu F. Specific antigen and organelle expression of a long-term rhesus endothelial cell line. In Vitro Cell Dev Biol 1987;23:75-85.

3. Grigsby JG, Parvathaneni K, Almanza MA, Botello AM, Mondragon AA, Donald MA, Tsin TCA. Effects of tamoxifen versus raloxifene on retinal capillary endothelial cell proliferation. J Ocular Pharma Therap 2011;27(3):225-233.

4. Munderloh $U$, Lynch MJ, Herron MJ, Palmer AT, Kurtti TJ, Nelson RD, Goodman LJ. Infection of endotelial cells with Anaplasma marginale and $A$. phagocytophilum. Vet Micro 2004;101:53-64.

5. Machuca FS. Implementación de un cultivo de células endoteliales de origen primate [tesina licenciatura]. Jiutepec, Morelos: Universidad Politécnica del Estado de Morelos; 2014.

6. Dawson JE, Rikihisa Y. Growing Ehrlichia species in a continuous cell line. US patent 5,192,679; Mar 9, 1993.

7. Wellman ML, Krakowka S, Jacobs RM, Kociba GJ. A macrophage-monocyte cell line from a dog with malignant histiocytosis. In vitro Cell Dev Biol 1988;24(3):223-229.

8. Granjeno CG, Machuca FS, Rodríguez CSD, Vega YMCA. Mantenimiento de las líneas celulares RF/6A del mono Rhesus y DH82 del perro doméstico. $1^{\mathrm{a}}$ ed. Morelos, México. CENID-PaVet / INIFAP; [EN PRENSA] 2015.

9. Hegarty BC, Levy MG, Gager RF, Breitschwrdt RF. Immunoblot analysis of the immunoglobulin $\mathrm{G}$ response to Ehrlichia canis in dogs: An international survey. J Vet Diag Invest 1997;9:32-38.

10. Keysary A, Trevor W, Strenger C, Harrus S. Cultivation of Erlichia canis in a continuous BALB/C mouse macrophage cell culture line. J Vet Diag Invest 2001;13:521-523.

11. Granjeno CG, Machuca FS, Rojas REE, Amaro EI, Preciado DLTJF, Rodríguez CSD, Vega YMCA. Interacción entre eritrocitos infectados con Anaplasma marginale y las estirpes celulares permisivas DH82 y RF/6A [resumen]. Reunión Nacional de Investigación Pecuaria. Mérida, Yucatán. 2014:4.

12. Heinrich $F$, Bono-Contioso V, Stein VM, Carlson R, Tipold A, Ulrich $\mathrm{R}$, et al. Passage-dependent morphological and phenotypical changes of a canine histiocytic sarcoma cell line (DH82). Vet Immunol Immunopathol 2015;163:86-92.

13. Fragoso SH. La anaplasmosis bovina en México. En: Vega YMCA et al. editores. 20 Seminario Internacional de Parasitología Animal. Oaxtepec, Morelos. 1993:153-160.

14. Vega YMCA. Actualidad e importancia de las enfermedades causadas por los hemoparásitos En: Vega YMCA et al. editores. $2^{\circ}$ Seminario Internacional de Parasitología Animal. Oaxtepec, Morelos. 1993:144-152.

15. Luna CGS, Rodríguez CSD, Ramírez NP, Preciado DLTJF, Rojas REE, Mosqueda GJJ, Vega YMCA. Cultivo in vitro de Anaplasma marginale en líneas celulares endoteliales. Rev Mex Cienc Pecu 2010;1(4):373-390.

16. Microsoft $\circledast$ Office Excel 2007: Funciones estadísticas.

17. ATCC. ATCC $®$ Animal Cell Culture Guide, tips and techniques for continuous cell lines. https://www.atcc.org/ /media/ PDFs/CultureGuides/AnimCellCulture_Guide.pdf Accessed: 29 Jan, 2014.

18. Kasai A, Shintani N, Oda M, Kakuda M, Hashimoto $H$, Matsuda T, Baba A. Apelin is a novel angiogenic factor in retinal endotelial cells. Biochem Biophysical Res Com 2004;325(2):395-400.

19. Shen $\mathrm{S}, \mathrm{Yu} \mathrm{H}$, Chen $\mathrm{P}$, Yin J, Xiong YK. Fatty acids in tea shoots (Camellia sinensis (L) O. Kuntze) and their effects on the growth of retinal RF/6A endotelial cell lines. Mol Nutrition Food Res 2007;51:221-228.

20. Cajero-Juárez M, Avila B, Ochoa A, Garrido-Guerrero E, Varela-Echavarria A, Martínez DLEE, Clapp C. Immortalization of bovine umbilical vein endothelial cells: a model for the study of vascular endothelium. Eur J Cel Biol 2002;81:1-8. 